\title{
Moose Hunters of the Boreal Forest? A Re-examination of Subsistence Patterns in the Western Subarctic
}

\author{
DAVID R. YESNER ${ }^{1}$
}

\author{
(Received 9 February 1988; accepted in revised form 7 July 1988)
}

\begin{abstract}
Many descriptions of lifestyles in the western subarctic region have been built on the premise that the hunting and use of moose was a central feature of those lifestyles. While this may be true, it is worthwhile to question the time depth that underlies this adaptation and the degree to which it may have applied to former societies inhabiting the boreal forest region. Any such effort must include an analysis of available faunal remains from archaeological sites in that region. A consideration of the faunal record suggests that the intensive utilization of moose is relatively new in the western boreal forest, or at least was not widely characteristic of the late Holocene period. Thus, it cannot be assumed that the archaeologically designated late prehistoric "Athapaskan tradition" was isomorphic with modern subsistence regimes. To the degree to which large game played a central role in Athapaskan lifestyles, it was caribou, rather than moose, that seems to have dominated in the northern ecotonal region. Fish and small game seem to have dominated in importance in the southern coastal forest region, with a mixed subsistence economy characteristic of the central region. Historical factors, primarily involving widespread fires, habitat disturbance and impacts on predators, seem to be most responsible for the increase in moose numbers during the past century. The role of fire is particularly critical and may have had great influence on the nature and stability of past subsistence regimes in the boreal forest region, including impacts on both large and small game.
\end{abstract}

Key words: moose, western Subarctic, boreal forest adaptations, faunal analysis, fire ecology, late Holocene period, optimal foraging theory, Athapaskan tradition

RÉSUMÉ. Maintes descriptions des styles de vie dans la zone subarctique occidentale sont fondées sur l'hypothèse admise que la chasse et l'utilisation de l'original étaient une caractéristique fondamentale de ces modes de vie. Bien que cela puisse être vrai, il vaut cependant la peine d'enquêter sur la durée au cours de laquelle s'est faite cette adaptation, et sur le degré auquel elle a pu s'appliquer aux anciennes sociétés qui habitaient la zone de la forêt boréale. Une entreprise de ce genre doit comprendre une analyse des restes fauniques disponibles, trouvés sur les sites archéologiques de la région. L'étude de ces vestiges fauniques laisse supposer que l'utilisation poussée de l'original est relativement nouvelle dans la forêt boréale occidentale, ou du moins, qu'elle n'était pas une caractéristique généralisée de l'holocène supérieur. Ainsi, il n'est pas possible de supposer que ce qu'on appelle en archéologie la «tradition athapaskienne» préhistorique tardive et des régimes de subsistance modernes sont isomorphes. Dans la mesure où le gros gibier jouait un rôle central dans le mode de vie des Athapaskans, c'est le caribou plutôt que l'orignal qui semble avoir dominé dans l'écotone septentrional. L'importance du poisson et du petit gibier semble avoir été dominante dans la région de la forêt côtière méridionale, avec une économie de subsistance mixte, caractéristique de la rẹgion centrale. Des facteurs historiques, incluant principalement des feux sur de grandes superficies, des perturbations de l'habitat, et des retombées sur les prédateurs, semblent avoir eu une contribution majeure dans l'augmentation des populations de caribous au siècle dernier. Le rôle du feu est particulièrement critique, et peut avoir eu dans le passé une grande influence sur la nature et la stabilité des régimes de subsistance dans la région de la forêt boréale, y compris des retombées sur le gros et le petit gibier.

Mots clés: orignal, Subarctique occidental, adaptations de la forêt boréale, analyse de la faune, écologie des feux, holocène supérieur, théorie du fourrage maximal, tradition athapaskienne

Traduit pour le journal par Nésida Loyer.

\section{INTRODUCTION}

Recent problem-oriented studies in the prehistory and protohistory of the western Subarctic have focused primarily on the issue of Athapaskan "ethnogenesis," i.e., the question of the time depth of Athapaskans in western North America, their place of origin, and their recognition in the archaeological record of Alaska and western Canada (Helmer et al., 1977). Lack of well-dated sites for the mid-Holocene period have complicated the ability of investigators to draw clearcut linkages through time. A somewhat related problem, however, that has not been addressed to any extent, is the degree of continuity in the subsistence base of subarctic populations over time. Using a direct historical approach, it is frequently assumed that prehistoric antecedents of modern Athapaskan cultures lived an essentially identical lifestyle. Thus, the term "Athapaskan tradition" has found recent favor as a unifying concept linking prehistoric, protohistoric, and historic cultures since ca. 1000 A.D. in interior Alaska and adjacent Yukon Territory. To what degree is this a valid concept?
In Alaska, penetration of the Hudson's Bay and RussianAmerican companies into the interior was relatively late, but effects of contact were also felt in advance of actual European occupation, particularly widespread trade items. Intensification of caribou exploitation in the late 19th century by groups in the northern interior, including the construction of large caribou fences, may have been at least partially a consequence of European contact. Given this situation, it is worth questioning the degree to which ethnographic descriptions of Alaskan Athapaskan adaptations - many of which date only to the early part of this century - reliably describe even protohistoric lifestyles.

A particular aspect of this is the relative importance of moose as a food staple for interior Athapaskan populations. VanStone (1974), Nelson (1973), and others have stressed the importance of moose to Athapaskan populations. Nelson has discussed the complexity of technology developed by Athapaskans for moose hunting and the individual skill that it required. Similarly, VanStone has suggested that moose were probably the most important terrestrial mammalian resource to Alaskan Athapaskans, second only to salmon for

\footnotetext{
${ }^{1}$ Department of Anthropology, University of Alaska, 3211 Providence Drive, Anchorage, Alaska 99508, U.S.A.

(c) The Arctic Institute of North America
} 
some groups, and that the focus on hunting this solitary browsing animal was the basis for the development of many highly individualistic social and religious institutions in Athapaskan society. On this basis, also, some recent ethnoarchaeological studies have been taken of patterns of moose hunting and butchering, as well as the spatial structure of moose hunting camps, with implications for application in a broad sense to past Athapaskan communities (cf. Janes, 1983). Is this really justified by the biological and archaeological data for past moose distributions and utilization?

\section{PALEOENVIRONMENTS: CLIMATIC CHANGE AND} THE ROLE OF FIRE

Biological data on past distributions of moose populations are difficult to obtain. Early journals nearly always mention moose, but it is difficult to gauge the numbers that were present. As in the adjacent Yukon Territory, moose seem to dominate as a resource only in the more closed central boreal forest region in the central and southcentral portions of interior Alaska. To the north, in the more open forest/tundra ecotone historically occupied in the Kutchin, caribou were the most important mammalian resource. Along the southcentral coast, only limited habitat was available for moose in precontact times; Klein (1965), in his review of "Postglacial distribution patterns of mammals in the southern coastal regions of Alaska," has suggested that, at the present time,

Extensive occupation of the southern coastal regions of Alaska by moose cannot be expected, because suitable habitats are restricted to a few sizeable areas where the vegetation is still in early stages of succession and which occur only in the larger river valleys of the mainland and on the terminal moraines of glaciers that have receded recently. Moose have been successfully introduced [however] to the Copper River delta.

[Klein, 1965:17.]

Climatic changes associated with the end of the "Little Ice Age" around the mid-19th century could be expected to have had some impact on floral composition and thus the habitat areas of caribou and moose (Hatter, 1948; Anderson, 1974; Bishop and Rausch, 1974), although how much is difficult to say since it evidently cannot be detected by pollen analysis. Published radiocarbon-dated pollen diagrams available from the southcentral Alaskan region include the Hidden Lake diagram from the Kenai Peninsula, the Point Woronzof diagram from northern Cook Inlet, the 70 Mile Lake diagram from the Copper River lowland, and the Tangle Lakes diagram from the Gulkana Upland (Ager and Brubaker, 1985; Ager and Sims, 1981a,b; Ager, 1982, 1983, 1984,1985 ). Although details differ in each case, there are some overall similarities. A spruce-alder-birch zone apparently became established throughout much of the region by ca. 7800 B.P. However, in the Kenai Peninsula region, this process was somewhat retarded, so that spruce did not become fully established for another 2000 years (until ca. 5500 B.P.). In the Gulkana Upland, spruce seems to have disappeared for a time but reappeared by ca. 3500 B.P. Slightly later - perhaps as late as 2000 B.P. - a moist coastal forest consisting of Sitka spruce and hemlock invaded the Kenai Peninsula region from the east. Both of these phenomena - the invasion of spruce into the Gulkana Upland and the invasion of Sitka spruce and hemlock into the central Kenai Peninsula - appear to be unrelated to climatic change per se. However, Ager and Brubaker (1985) have interpreted the increase in willow and Cyperaceae in the 70 Mile Lake core as reflective of Neoglacial cooling. Unfortunately, however, the pollen record is apparently not very sensitive to climatic changes within the last 1000 years (Ager, pers. comm. 1986). However, another source of data - the glacial record - does suggest an overall environmental cooling in the region associated with the "Little Ice Age" (ca. 1300-1850 A.D.). Perhaps as a result of a greater moisture regime as well, glaciers seem to have expanded to a maximum by the midto late 19 th century, a point from which they are now almost universally in retreat. Recent work in the Portage Glacier region (Crossen, 1988), using a combination of dendrochronology and lichenometry, has suggested maximum glacial expansion in the early 19th century, perhaps one of the most extensive expansions in postglacial times. If so, then a greater amount of moose habitat may have been available than in either earlier or later periods.

In addition, boreal forest subsistence would have been affected by alterations in snow cover related to these climatic changes. For example, Winterhalder (1982:208) has noted that

Snow depth affects [both] forager mobility and the distribution of prey. . . . Deep snows may also reduce the moose population by starvation. Conversely, shallow snow may cause the death of large numbers of small mammals . . . through exposure.

Thus, deeper snows may reduce the populations of moose by making location of food sources more difficult (Coady, 1974), while they may enhance the survival probability of small mammals that depend on snow cover for subnival survival over the winter (Merritt, 1984). All other things being equal, therefore, variations in snow cover should lead to changes in the relative importance of large and small game.

In reviewing evidence of historical trends in usage of boreal forest environments, furthermore, several authors have noted that no single, fixed subsistence pattern should be expected in an area for more than a few hundred years at the most, and often for a lot less. Feit (1969), for example, argues that the role of big game, including both moose and caribou, has been "stressed at the expense of smaller game" and proposes an alternative hypothesis, based primarily on the frequency of fires in the boreal forest zone:

during the cycle of development of the vegetation from burn to coniferous forest a succession of different resources were available in the environment and a succession of different subsistence patterns were adapted by the Indians in order to utilize these resources for human subsistence. Over a period of two or three centuries no single winter resource was primary and none secondary for the entire period. [Feit, 1969:94; cf. Wein and MacLean, 1983.]

Feit concludes that for the boreal forest zone "the data indicate that there would have been no permanent dependence on large game but rather a regular cycle of differing resources and subsistence patterns in aboriginal times" (Feit, 1969:138). Furthermore, increased utilization of fire as a management technique by late prehistoric populations must be considered as an additional factor affecting both large and small game populations at this time (cf. Lewis, 1977).

In sum, in the absence of more direct evidence, we may speculate that species such as bear or beaver were generally available for subsistence in the boreal forest region, but that 
populations of the large herbivores (moose, caribou) underwent long-term changes in response to both climatic change and natural population cycles, and that populations of small game (e.g., snowshoe hare) probably underwent more frequent fluctuations on a shorter time scale. These processes must have affected the fortunes and lifestyles of human groups in the interior.

LeResche et al. (1974) undertook a comprehensive study of historic patterns of moose distribution in Alaska. They concluded that, beginning in the late $1950 \mathrm{~s}$, "moose numbers appeared to be rising throughout much of interior Alaska" (LeResche et al., 1974:151). They attributed this phenomenon to an increased prevalence of wildfires. In particular, they noted that

\begin{abstract}
Many of the interior Alaska areas now most heavily used by moose . . . are burns that date from 1957, when an estimated 12.5 million hectares burned in Alaska ... . distribution of moose is materially affected by the prevalence and successional stage of fire site vegetation dating from that year. [LeResche et al., 1974:151.]
\end{abstract}

To the south, they noted that development, agriculture, and fires in the Matanuska-Susitna region had greatly increased moose numbers there, so that "moose populations reached their higher recorded densities over much of the area in the late 1950s" (LeResche et al., 1974:150). In the Copper River and Upper Susitna River regions, they cited Chatelain (1952) in noting that "moose were increasing rapidly in this general area in response to extensive fires over the preceding 30 years" (LeResche et al., 1974:151), although they implicated other factors, such as elimination of wolves and land use change (Leopold and Darling, 1953). Zagoskin (1967) had previously reported low numbers of moose in the southwestern Alaskan region.

In the north, the pattern of historic moose population expansion is even clearer. For example, LeResche et al. (1974) noted that moose were first seen in the Upper Koyukuk region in the 1920s and also that "moose have significantly extended their range [in] northwestern coastal Alaska"' (LeResche et al., 1974:152). They found this pattern interesting, particularly in light of earlier archaeological findings in the region:

Hadleigh-West (1966) found no moose remains in archaeological excavations of two houses at Ogotoruk Creek, near Cape Thompson on the northwest coast. The houses had been occupied from about $1880-1900$ until recently. ... What accounts are available ... suggest a gradual increase in moose numbers similar to that in the central Brooks Range. [LeResche et al., 1974:152.]

Clark (pers. comm. 1987) has found similar historic increases in moose numbers in the Koyukon region. Citing data from Schwatka (1892) and others, he notes that

Moose were not always [as] available [as at present] to the Koyukuk Indians and Eskimos. During the last decades of the preceding century and the first two decades of the present century, there reportedly were none in the drainage (native tradition) . . . in the 1860's Dall and Whymper had noted that there were no moose along the main river. . . . We do not know if the conditions observed by Dall and Whymper represent the downside of a former cycle of abundance, or a long-enduring condition in which moose were rare. [Clark, n.d.:90-91.]

\section{BOREAL FOREST ADAPTATIONS: THEORETICAL CONSIDERATIONS}

More direct reconstructions of late Holocene cultural adaptations in the boreal forest zone are limited by taphonomic factors, specifically the lack of preservation of faunal (and floral) remains in all but a handful of archaeological sites. Sites in the forested interior are generally limited to preservation of inorganic materials. Before proceeding to discussion of the relatively limited archaeological record, however, it may be useful to consider some cautionary tales about understanding lifeways in the boreal forest region.

In a recent book, Winterhalder (1982) described some of the relevant features of what he terms "boreal foraging strategies," by utilizing a combination of detailed ecosystem analysis and the principles of optimal foraging theory. In this light, relevant features of boreal foraging strategies are seen to include the following principles:

(1) In the boreal forest environment, low biomass of edible plant foods forces reliance on animals as the major prey species.

(2) These species are generally "low in density, solitary or in small groups, and well-dispersed," but occasionally "some aggregation occurs for reasons of habitat" (Winterhalder, 1982:209).

(3) The boreal forest is a patchy environment, because of variations in water supply (streams, lakes), topography (lowlands, uplands, broken terrain), and vegetation types. Among the latter, four types tend to stand out: (a) mature forest; (b) recent burn; (c) vegetation of river/lake margins; and (d) aquatic vegetation. Each patch is "different with respect to the game it attracts and the impediments it places between forager and prey. When mapped, these habitat patches show an irregular distribution of small-scale vegetation zones" (Winterhalder, 1982:208).

(4) Each species of game, therefore, is "probablistically associated with one or more vegetation patch-types, and is therefore somewhat localized in distribution" (Winterhalder, 1982:209).

(5) Many species (as indicated above) are subject to marked population fluctuations over short-term or longer term intervals. Although not discussed by Winterhalder, fertility factors intrinsic to the population dynamics of a number of primary consumers may be implicated. Critical extrinsic factors cited are the timing of freeze-up and break-up, stream flow levels, and quality and quantity of the depth of snow cover. In addition, the frequency of fires is critical in altering the seral stages of vegetation. Thus, "the landscape mosaic is a dynamic one: fire, wind, and snow disturbances constantly change the distribution of vegetation"' (Winterhalder, 1982:208).

(6) Boreal foragers tend to place emphasis on the hunting of large game animals. These will be taken preferentially if available. Among the animal species available in the boreal forest, they return the greatest yield for time and energy invested in harvesting. This would be particularly true for caribou, which tend to aggregate in particular habitat zones; however, woodland caribou, as well as moose, can be quite erratic in terms of aggregation. Furthermore, as emphasized elsewhere (Yesner, 1981), optimal foraging theory, based purely on caloric considerations, often cannot fully explain the full suite of exploitation patterns observed among hunter- 
gatherers. Other species, for example, would likely have been exploited primarly for high body fat content, particularly during the winter (e.g., beaver); others are particularly easy to catch during the winter, when other resources are less available (e.g., snowshoe hare). These species, often highly "ranked" by hunter-gatherers in spite of their relatively low efficiency of caloric return, may have had a critical periodic role in the survival of boreal foragers.

(7) Actual foraging patterns in the boreal forest must be related to the specific mix of resources available at various points in time. In general, because the environment is relatively patchy, a greater amount of time is spent in searching for, rather than pursuing, game, in contrast to strategies among Eskimo foragers. Given that situation, optimal foraging theory predicts that a wider variety of species should be utilized - i.e., wider "dietary breadth" - and therefore that a relatively larger proportion of species encountered will actually be pursued. More game will be taken "as encountered." However, where patches are larger, greater specialization would be predicted, because "travel time between exploited patches is a linear function of environmental dimensionality, whereas hunting time is a squared function" (Winterhalder, 1982:206). Furthermore, during periods in which preferred prey (big game) become more abundant, average search time will be reduced and greater specialization should also occur. Conversely, during periods in which such species are rare, dietary breadth should be particularly wide, more "co-harvesting"' of species (cf. Yesner, 1981) should occur, and factors other than calories alone may become important.

(8) Following Horn's model (Wilmsen, 1973), settlement patterns in the boreal forest should have more to do with the distribution and predictability of game than with animal size per se. If large, predictable aggregations - e.g., of anadromous fish or caribou - are available, larger settlements close to resource locations would be expected. Resources that are aggregated but less predictable as to exact location - e.g., mountain sheep or marmot - would engender a central-based foraging strategy. Finally, where resources are more evenly dispersed (e.g., snowshoe hare), dispersion of social units will tend to occur, and these species will tend to be taken "as encountered." In reality, boreal forest habitats offer a mix of species, and the settlement pattern for a particular region should reflect a mix of these strategies. However, as one of these categories of resources - e.g., caribou or snowshoe hare - becomes more abundant, one would predict a settlement pattern shift in that direction. (Snowshoe hare, of course, have a relatively low body fat content, and a fish/hare subsistence is often only one step above starvation [unless it involves anadromous fish with a higher fat content]. In addition, hares can be used for the manufacture of certain types of clothing; caribou or moose skins, however, are required for others, as well as the production of babiche for snowshoes and other items. However, hares are widely dispersed in the boreal forest, and may [like shellfish, for those who live on the coast] represent a staple resource that prevents starvation.)

These paleoenvironmental, ethnohistoric, and biological data concerning game availability and distribution can be used to develop predictive hypotheses to be tested on the archaeological record from the western Subarctic. One prediction, for example, would be that moose remains should be relatively rare in archaeological samples predating the last few hundred years, with substantial numbers found only in very late sites. Another prediction would be that at certain times and places, small game should dominate the faunal inventory. To what degree are these predictions borne out by the archaeological record from the region?

\section{THE ARCHAEOLOGICAL RECORD OF INTERIOR ALASKA AND THE YUKON}

Late Holocene archaeological sites in the interior of Alaska with well-preserved faunal remains (Fig. 1) clearly show a dichotomy of subsistence patterns, perhaps best expressed in terms of Cleland's (1966) concept of "focal" and "diffuse" economies. According to this concept, "focal" economies - concentrating on the exploitation of fewer numbers of species - would occur when certain preferred species were sufficiently abundant (and reliable). Although the total dietary breadth may be equally large (i.e., the same total number of species exploited), in a focal economy a much larger percentage of the individuals taken will be from only one or a few species - i.e., the average dietary diversity is relatively low. Gadacz (1975) argues that this concept should be applicable to subarctic economies, as it is useful in contrasting large game specialization vs. generalist strategies developed in that region.

The late prehistoric record from the interior of Alaska and the adjacent Yukon Territory shows evidence for both "focal" and "diffuse" economies, but it is clear that "focal" economies were everywhere dependent on caribou rather than moose. The "focal" economy of the Gulkana Upland, for example, is well reflected in the faunal assemblage from the Paxson Lake Knoll and Point sites, GUL-079, as analyzed several years ago (cf. Yesner, 1980; Ketz, 1983; Yesner and Bonnichsen, 1979). At that site, beaver, muskrat, wolverine, porcupine, mink, ground squirrel, wolf, and lemming or vole, as well as caribou, were represented. However, of the more than 6200 faunal remains recovered from the site, fully $99 \%$ represent caribou remains, probably related to exploitation of the Nelchina Herd (Hemming, 1972). (Although 4000 of these bones [ $63.6 \%$ of the total] could not be definitively identified to species, all of the 2200 identifiable large mammal bones were caribou.) This reflects $83.6 \%$ of the numbers of individual animals present at the site. Depending on the particular measure used, the diversity of the assemblage is very low $(\mathrm{H}=.19$ on a scale of $1-10)$. The Butte Lake site, also near the Denali Highway, shows a similar pattern of concentration on caribou in a late prehistoric "Athapaskan tradition" component; there, caribou remains constituted over $99 \%$ of the total faunal assemblage, and "no large mammal faunal remains, other than caribou, were identified at the site" (Betts, 1988:16).

Other late prehistoric sites with good preservation of faunal assemblages from the northern interior show nearly identical exploitation patterns. For example, at the Croxton site on Tukuto Lake in northern interior Alaska, dated to ca. 1380 A.D., Spiess and Gerlach (1983) identified a faunal assemblage consisting of ca. $99.3 \%$ caribou bone; only 29 bones of nearly 4000 could be attributed to other species, and, as at Paxson Lake, none of these could be attributed to moose. (As at Paxson Lake, ca. 2300, or 59\%, of the bones could not be definitively attributed to caribou, but all of the 


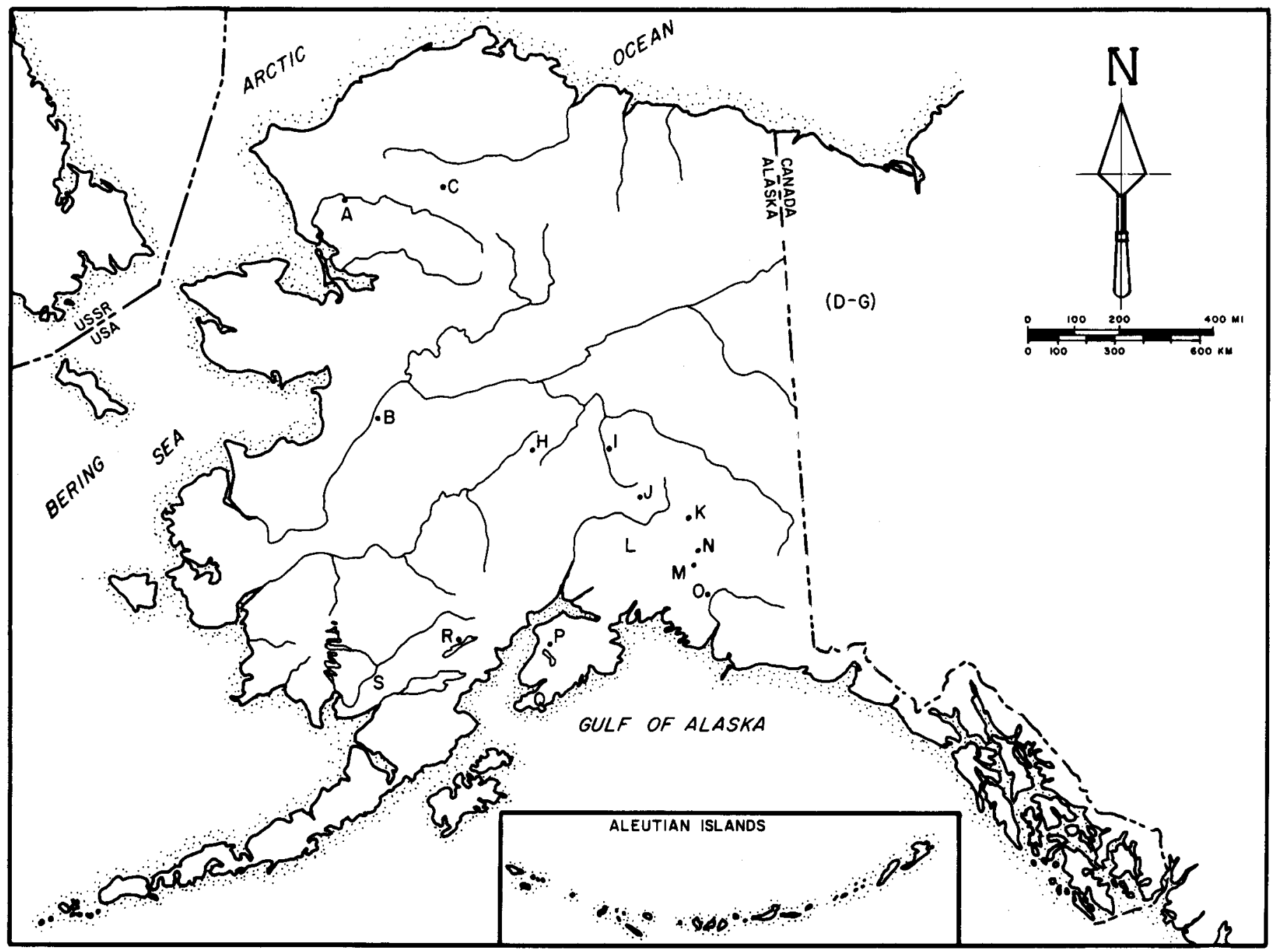

FIG. 1. Location of archaeological sites mentioned in the text: A) Kangiguksuk (Noatak River); B) Old Fish Camp (Khotol River); C) Tukuto Lake; D) Rat Indian Creek; E) Old Chief Creek; F) Cadzow Lake; G) Klo-kut (Porcupine River); H) Minchumina Lake; I) Nenana Gorge; J) Butte Lake; K) Paxson Lake; L) Susitna River region; M) Tazlina Lake; N) Ringling (Gulkana River); O) Dakah De'nin's Village (Copper River); P) Squilantnu, Sterling (Kenai, Russian Rivers); Q) Yukon Island (Kachemak Bay, Cook Inlet); R) Kijik (Lake Clark); S) Nushagak River.

1600 identifiable large mammal bones were caribou.) The overall diversity of the faunal assemblage is again very low $(\mathrm{H}=0.168)$. A similar pattern was found at the nearby Sikoruk site, dated to ca. 1450 A.D. (Spiess and Gerlach, 1983).

Very similar faunal distribution patterns to those from sites in the northern Alaskan interior (tundra/forest ecotone) are found in sites from the northern Yukon Territory. For example, at LeBlanc's (1984) Rat Indian Creek site, the faunal assemblage, analyzed by J. Kolar, shows a similar distribution, with $98.1 \%$ of the 24000 identifiable faunal elements attributable to caribou, and only $0.3-0.4 \%$ contributed apiece by moose, hare, beaver, and muskrat (LeBlanc, 1984). At the Old Chief Creek site, also on the Middle Porcupine River drainage, Kolar (1980) again analyzed a large collection of faunal materials, comprising some 45000 bones. Of these, Kolar considered only 4225 bones, or ca. $9.3 \%$ of the total assemblage, to be identifiable. (A more restricted sample from house pits showed a similar percentage of identifiable specimens: 76 out of 895 , or $8.5 \%$.) Of these specimens, 3790 , or $89.7 \%$, were attributable to caribou. The next most important species were muskrat $(\mathrm{N}=282)$, snowshoe hare $(\mathrm{N}=40)$, and beaver; moose specimens were comparatively rare. The total diversity for this assemblage is again low $(\mathrm{N}=.108)$.

Even at the nearby 19th-century Cadzow Lake site (Morlan, $1973)$ only three elements $(0.1 \%$ of the assemblage) were contributed by moose, while 2096 elements $(93.8 \%$ of the assemblage) were contributed by caribou. The Klo-kut site (Morlan, 1973) in the same region shows a similar distribution: there, of 14000 bones assigned to the late prehistoric period, $94.3 \%$ are attributable to caribou, with only $3 \%$ attributable to muskrat, $1.5 \%$ to fish, and $1.2 \%$ to other small mammals and birds. A diversity index based on the minimum numbers of individuals (MNIs) from site $\mathrm{M}_{\mathrm{J}} \mathrm{Vl-1}$ (Klo-kut) is higher than at Paxson Lake $(\mathrm{H}=0.66)$, however, because although caribou represented $94.3 \%$ of the faunal elements (Morlan, 1973:417-Table 73), they constituted only 42\% of the MNIs (Morlan, 1973:431-Table79). Essentially the problem is again one of unequivocal attribution of highly comminuted caribou long bone, pelvis, scapula, and mandible fragments. 
These fragments derive both from the initial butchering processing and from subsequent caching of meat sections. They also derive from direct processing of caribou bones for marrow production, grease rendering, and stone boiling (Binford, 1978), as well as the manufacture of both expedient and systematic bone tools, particularly from metapodial shafts (Yesner and Bonnichsen, 1979). Burning of caribou bone from cooking, refuse disposal, or accidental deposition processes may further alter capabilities for specific attribution of individual skeletal elements.

A good example of this occurs at site MMK-4 on Minchumina Lake in the central interior of Alaska (Holmes, 1986a). This site is one of the few that have been excavated in the central interior region of Alaska in which moose are the most prevalent today. Moose are, in fact, represented in this site, but only by two bones (3\% of the assemblage). Caribou remains also constitute only about $27 \%$ of both the MNIs and the identifiable skeletal elements. If other unidentified large mammal bones are attributed to caribou at this site, however, then fully $75.5 \%$ of the faunal remains are caribou. Secondary resources included beaver, showshoe hare, and fish.

Slightly farther to the south, in the northern foothills of the Alaska Range, Plaskett (1977) has documented at the late prehistoric Nenana Gorge site a subsistence regime focused on a combination of caribou ( $37.9 \%$ of the assemblage) and Dall sheep $(45.1 \%)$, with only 17 bones $(4.1 \%$ of the assemblage) contributed by moose and three times as many $(12.2 \%)$ contributed by small mammals (hare, marmot, and ground squirrel).

More recently, a number of excavations have been undertaken in the central interior region as a part of the Susitna Hydroelectric Project (Dixon et al., 1985). Nearly 143000 faunal elements have been recovered from these excavations, of which over 125000 are from large mammals. Of these, however, only 1000 specimens could be definitively attributed to either moose or caribou, and caribou constituted $95 \%$ of this identifiable faunal assemblage. Furthermore, the stratigraphic record clearly indicated that none of the 54 moose bones recovered could be attributed to contexts predating 600 A.D., and the only radiocarbon date obtained from a moose bone sample was ca. 1580 A.D. (Saleeby and Dixon, 1986). Furthermore, even within that late prehistoric period, fully $93 \%$ of the large mammal faunal remains were attributable to caribou! The next most important mammalian resource was the snowshoe hare, but this constituted less than $1 \%$ of the total assemblage.

As one moves farther south toward the coastal region, small mammals and fish become increasingly better represented, although caribou continue to be important and moose are still of relatively little importance. For example, at the Tazlina Lake site in the pass between the Susitna and Copper River lowlands, recently excavated by Maschner (1987), caribou represent ca. $70 \%$ of the mammalian assemblage. Second in dietary importance were two small game species - snowshoe hare and red squirrel. Fish, including both salmonids and other species, constituted the remainder of the assemblage.

A very similar pattern is found at sites in the Copper River basin to the east, for which good quantitative subsistence data are available. At GUL-077 near Gulkana Village, excavated by Workman (1977), Lobdell (1976) found that caribou were still present. As at Minchumina Lake, they were only $12.8 \%$ of the total number of skeletal elements and only $9.1 \%$ of the minimum numbers of individuals (MNIs) from the site, but they would have contributed ca. $46.6 \%$ of the total food value. This is because small game constituted $58 \%$ of the assemblage and $50 \%$ of the MNIs. Beaver, snowshoe hare, and squirrel were the predominant mammalian species. Fish remains were also present but are difficult to quantify because of preservational factors (Lobdell, 1976).

These preservational (taphonomic) factors clearly create problems with comparability of the interior faunal assemblages. For example, at the Dakah De'nin Village site, also in the Copper River valley region, preservation of fish remains was sufficiently good that Shinkwin (1979) was able to identify 30590 salmon bones, constituting $97.7 \%$ of the entire faunal assemblage. However, $96.9 \%$ of these bones came from the excavation of one house pit (house 2); only $59.3 \%$ of the faunal remains were from fish in the other house pit (house 9). Of the large number of fish bones in house 2 , furthermore, fully $59 \%$ came from a single feature, variously interpreted as a cache or refuse pit. These tabulations demonstrate the danger in generalizing too much from the faunal assemblages found in individual site features, which can greatly skew the overall results. It also suggests that fish remains are much more likely to be recovered from storage or refuse features than general house pit fill.

In addition to differential preservation, different seasonality of site occupation may have led to different configurations of faunal assemblages at these sites. Lobdell (1976) has interpreted the Gulkana site as a spring occupation on the basis of the prevalence of beaver and snowshoe hare remains and the lack of permanent house structures. (Although caribou are thought to have been primarily fall fare for the Ahtna, they were known to have been taken in spring as well, and this is certainly verified by the faunal remains from Paxson Lake.) In contrast, the larger numbers of fish remains and the presence of more permanent house structures at the Dakah De'nin Village led to the conclusion that this was a site occupied from summer through winter. The fish bones, in particular, were said to be suggestive of summer as well as winter, since, based upon ethnographic analogy, "fish bones would not be present in fish dried for human consumption"' (Shinkwin, 1979:81).

Among the mammalian fauna represented at the Dakah De'nin Village site, snowshoe hare clearly predominated, constituting $70.6 \%$ of the assemblage. Other important species included small rodents. The overall diversity of the mammalian assemblage is moderate. In fact, the small game shows a similar pattern to that found at the Gulkana site. The large numbers of snowshoe hares at this site, in particular, are also suggestive of a winter occupation; in general, one would not expect large numbers of hare bones on a site used intensively in the summer.

The absence of caribou bones at this site, however, was attributed not to seasonal factors, but to butchering patterns, by which "these animals were slaughtered and the meat dried in the hills before returning to the winter settlements" (Shinkwin, 1979:80). It is also notable in this context that the virtual absence of King Salmon among the salmonid fish remains was again attributed not to seasonality (i.e., lack of early summer occupation of the area) but to some other aspect of species preference. Black bear was the only large animal represented, by two skeletal elements. 
A very similar pattern to that from the Dakah De'nin Village site is represented at another riverine site, Old Fish Camp on the Khotol River (Ream, 1986). Here, of the total 5700 identifiable bone fragments from the site, 185 represented caribou, or ca. $3.2 \%$ of the assemblage, while fish (salmonids) represented $89.3 \%$ of the assemblage. If, however, fill samples are examined exclusive of house floor samples, then caribou represent nearly twice as much, or $5.8 \%$ of the sample, and when adjusted for meat weight probably represent ca. $25 \%$ of the sample. Importantly, no other large game animals were represented; the only other mammalian species important at the site was the snowshoe hare, constituting $5.1 \%$ of the fill and $2.0 \%$ of the total faunal assemblage. Other small mammals exploited there included muskrat, red squirrel, mink, and marten (Ream, 1986: 547-548).

Recently, additional data on protohistoric subsistence in the Kenai Peninsula region of southcentral Alaska have been forthcoming as a result of recent excavations by the Office of History and Archaeology, Alaska Department of Natural Resources, in the Cooper Landing region of the Sterling Highway (cf. Holmes, 1986b; Yesner, 1986). Three closely adjoining sites with late prehistoric components (SEW-214, KEN-092, and KEN-094) were excavated as a part of this project, yielding a sample of 13000 faunal remains. Of these, $82.7 \%$ could be attributed to snowshoe hare; this percentage did not vary much between sites. The largest sample of hare bones came from site SEW-214, which had $70.8 \%$ of the hare bones and $72.8 \%$ of the total faunal remains.

The second largest taxonomic category from the Sterling sites was fish (primarily salmonids). A total of 825 fish bone elements was recovered from the excavations, including 185 diagnostic remains such as vertebrae. While this represents only ca. $13 \%$ of the numbers of snowshoe hare individuals recovered from the site, in terms of meat weight it probably represented about $74 \%$ of that contributed by hares (ca. 275.4 $\mathrm{kg}$ ), similar to the findings at Dakah De'nin's Village. It is further notable that at other sites in the area - e.g., at SEW-187a - fishbone (from salmonids) constituted as much as $78.6 \%$ of the total faunal assemblage (Yarborough, 1983).

As at Dakah De'nin's Village, also, a variety of small mammals were exploited. Although the assemblage was dominated by snowshoe hare, a number of other species were also present, including squirrel, marmot, beaver, porcupine, muskrat, and otter. The first two taxa (squirrel and marmot) represent $65.3 \%$ and $20.5 \%$ respectively of the non-hare small mammal assemblage; the diversity of this assemblage is similar to that at Dakah De'nin's Village. In addition, as at the former site, bear was the only large mammal represented at the site, although Dall sheep is also represented by a total of 38 identifiable skeletal elements. These two taxa were distributed very differently in the sites: Dall sheep remains were associated with house pit fill, while bear bones were found only in external cache or refuse pits (verifying ethnographic suggestions of special treatment given to these bones). (Dall sheep, of course, represents a relatively specialized alpine adaptation within the interior boreal forest region.) Indeed, it may be suggested that marmot contributed the critical element of winter fat in the diet. It may also be for that reason that marmot is the best represented terrestrial animal in archaeological sites in Kachemak Bay to the south (Yesner, 1988).
Apparently neither caribou nor moose was represented at this site, again reflecting a similar picture as at Dakah De'nin's Village. Does a similar explanation given for the lack of caribou remains at Dakah De'nin's Village also apply to the Sterling site assemblages? It seems more difficult here to argue that the lack of caribou remains was due to butchering in uplands away from the site, since the site is in an upland environment. It also seems difficult to argue that a late summer through winter seasonal pattern would have precluded the exploitation of caribou based from this site. The faunal assemblage from the nearby Moose River site (Lobdell, n.d.; Dixon, 1980) is also dominated by snowshoe hare (constituting $74 \%$ of the assemblage), but at this late prehistoric site some moose bones were found (constituting $12 \%$ of the assemblage). These data lead us to consider the whole question of explaining the observed patterns of caribou and moose exploitation in Alaska.

\section{EXPLAINING PROTOHISTORIC SUBSISTENCE IN THE BOREAL FOREST}

The overall impression that one gains in looking at all of the published faunal assemblages from interior Alaska is that moose appear only rarely in any of these assemblages until quite recent times, perhaps within the last 400 years. This holds not only for the tundra/forest ecotone to the north and the mixed spruce/hemlock forest on the southern coast, but also for the true boreal forest of the central interior region. Caribou exploitation was particularly intense in the northern tundra/forest ecotone of Alaska and adjacent Yukon Territory, but it also predominated as the most important large mammal in the central interior regions to the south. As one progresses southward, small mammals become more important, although fish are more important in areas where they are locally available. Protohistoric subsistence in some southern regions, such as the Kenai Peninsula, appears to have been dominated by small game and fish, with even caribou not apparent in the faunal assemblages.

One way to explain this general phenomenon is to appeal to aspects of site seasonality or visibility. All of these sites, for example, may be considered seasonal sites, although somewhat different seasons may be expressed. Beginning in the tundra/forest ecotone to the north, both the Klo-kut and Paxson Lake sites can be definitively established as spring hunting locales on the basis of the remains of perinatal caribou and individuals grouped in the 10-15 and 22-27 month age groups. The Tazlina Lake also appears to represent spring occupation (Maschner, 1987). In fact, the fragmentation of long bones as a part of the process of bone grease/soup production makes particular sense as an attempt to provide nutrient-rich foods during this resource-poor time of year (cf. Binford, 1978:157-165). However, other sites showing the same degree of intensive caribou exploitation have been demonstrated to be fall hunting camps or winter village areas; a good example of this is the Croxton site (Spiess and Gerlach, 1983). Although none of these sites gives a full picture of the seasonal round of any group, it is difficult to accept site seasonality as a total explanation of the observed pattern. One possible factor may simply be the relatively small sample of sites. Yet another possibility is related to butchering patterns and meat transport: moose bones would have been far less likely to be represented in site faunal assemblages 
if the animals were killed at some distance from the site. The large size of moose would encourage either drying of meat at the kill location or boning out the meat in order to lighten the load before transportation back to camp, as noted by Shinkwin (1979), based on Campbell's (n.d.) Ahtna field notes. (See O'Connell et al. [1988 a,b] for a recent discussion on the general relationship between "boning out" of large animal carcasses and transport distances to campsites.)

On the basis of the available evidence, however, one is forced to conclude, along with Morlan (1973:576-577), that caribou were the most important species hunted by most Athapaskan groups, with "the largest villages of such groups . . . centered around communal caribou hunting localities," and that this pattern applied to much of central Alaska, except for the southern coastal zone.

Is it possible that moose were available in the boreal forest but simply not exploited by human populations? The only justification for such an argument would be if moose, in spite of their large size, were perceived as energetically expensive to exploit because of their less frequent aggregation in large numbers in comparison to caribou. However, the per unit ratio of biomass yield for energy expended in hunting moose is so high that one would expect that in times of decline in caribou numbers in late prehistoric times one would see exploitation of moose if they were available, even as a less preferred resource.

There is no question that such fluctuations in caribou population took place. As Burch (1972:356) has noted, "caribou populations experience long-term fluctuations independently of factors of human predation." As noted above, these fluctuations may result from extrinsic factors such as small-scale climatic changes or changes in the frequency of fires; they may also involve factors intrinsic to the caribou populations. These fluctuations may even be demonstrated archaeologically. For example, at Paxson Lake it was noted that

some changes in the faunal assemblages of various strata in the cache pit excavations may reflect short-term fluctuations of caribou populations between periods of occupation at the Knoll site. Temporal differences between the Knoll and Point site occupations may also represent site abandonment during a period when caribou populations foundered, followed by reoccupation of a different area. For example, the area may have been abandoned during the caribou population "low" of the late 19th century, then reoccupied during the 1920's. This might also explain the trapping activities involving small fur-bearers in the upper layers of both the Knoll and Point sites. [Yesner, 1980:23.]

Recently, Gronnow et al. (1983) have demonstrated a similar phenomenon in their excavation of the Aasivissuit site, a late prehistoric caribou hunting site in the interior of the Nuuk district, West Greenland. Gronnow et al. (1983:86-87) are able to demonstrate that historically documented fluctuations in caribou populations can be verified in the archaeological record, and that this evidence extends well back into the "neoEskimo" period. These lines of evidence include both changes in the intensity of caribou utilization and site abandonment.

In his comments on the symposium on boreal forest archaeology and ethnohistory at the 1987 annual meeting of the Society for American Archaeology, Donald Clark suggested that such site abandonment may occur when caribou populations shift between microenvironments within a region.
He notes that in the Koyukuk River region failure of the caribou population in the late 19 th century led not only to starvation, but to "major movements out of part of the river to other areas along the Koyukuk River and elsewhere."

The strategy of site abandonment as an aspect of traditional lifeways in the northern part of the boreal forest region brings us to the second major possibility in explaining the predominance of caribou hunting sites in the north: the greater archaeological "visibility" often suggested for such sites (cf. Burch, 1972). Even if moose were not widely exploited, for example, one would expect to see more small game hunting sites during periods in which caribou were less available. Perhaps the lack of such sites in the northern portion of the boreal forest could just be attributable to a lower "visibility" for such site types; this would apply to both moose and woodland caribou. However, an alternative explanation is possible, based on an understanding of the ecology of the region and principles of optimal foraging theory cited above. To begin with, in the forest/tundra ecotone region, extensive fish runs were not available to buffer human populations. Whitefish, burbot, grayling, lake trout, and northern pike were locally available in lakes and rivers, but never represented an aggregate resource like salmon (or other anadromous fish) that could be intensively harvested. Small game was also relatively scarce, and the most important species was the snowshoe hare, an auxiliary species and one that was subject to population fluctuations of an even shorter time scale than caribou. Given that scenario, site abandonment would have been a more profitable strategy than remaining in those regions during periods of caribou population decline. From a theoretical viewpoint, site abandonment would be expected to occur when few other highly ranked resources (in terms of energy yields per unit effort) exist in a region when "preferred" resources (such as caribou) decline. During such periods of site abandonment, one would expect greater coalescence of populations into other areas. However, it may be difficult to detect such retrenchment of settlement patterns even for the late prehistoric and historic periods.

\section{SMALL GAME EXPLOITATION IN THE SOUTHERN FOREST REGION}

Following the principles of optimal foraging theory, the concentration on small game exploitation in the southern forest region must largely be a consequence of the lack of large game animals to exploit, since they should be favored whenever available. Explanation of the lack of caribou in the area may involve some combination of factors such as climatic change or fire disturbance. The first of these, as noted above, is very difficult to detect in the biological record. In the final section of this paper, therefore, I want to concentrate on evidence for high frequency of fires in that region as an explanation for the lack of caribou populations.

Numerous historic fires were recorded in the Copper River valley and Gulkana Upland zones (Lutz, 1956, 1959, 1960), and this could certainly have affected the availability of both caribou and moose in the region. Fire disturbance was also clearly documented for the Kenai Peninsula (Hardy and Franks, 1963; Barney, 1971; Viereck, 1973). Although extensive fires "of unknown origin" occurred during the late 19th century, Osgood (1904:27) suggested that during 
precontact times as well "accidental fires burned over wide regions with the same result." In general, because of the greater amount of precipitation in the Kenai and Copper River districts than in the uplands to the north, one would expect firing of the underbrush to occur less frequently. On the other hand, the fewer fires that did occur would be likely to have more widespread results. Thus, Spencer and Hakala (1964) agree that while "caribou were native to the Kenai," at the same time

the pattern of forest types on the Kenai ... is evidence that for a long period fire-caused vegetative changes have occurred.

[Spencer and Hakala, 1964:16.]

To some degree these patterns can be corroborated from the archaeological sites themselves. At site SEW-214 on the Kenai Peninsula, for example, there is evidence for extensive burning after the main house occupation, but this may relate to the late-19th-century fires. At KEN-092 and KEN-094, however, there is evidence for earlier burning, in the form of extensive charcoal deposits in the subsoil (McMahan, 1986).

Both regions - but particularly the Kenai Peninsula area - would also have been "marginal habitats for caribou" (Skoog, 1968) because of deeper snow in the coastal zone, precipitous terrain, and "rather limited suitable areas above timberline (i.e., extensive sedge-meadow and/or heath-lichen stands)" (Skoog, 1968:276). Given this situation, one would expect perhaps fewer but more pronounced fluctuations in caribou populations than in the upland environments to the north. Therefore, while we may be able to detect more subtle shifts in caribou herd patterns and in intensity of caribou exploitation in areas such as the Gulkana Upland, in areas such as the lower Copper River and particularly the Kenai regions there may have been longer periods of complete absence of caribou from the region, followed by repopulation from core populations to the north (Allen, 1904; Murie, 1935; Skoog, 1968).

Thus, in spite of the relative floristic richness of the Kenai Peninsula environment, it was a relatively marginal area for large game, being optimal habitat for neither caribou nor moose. However, the true extent of prehistoric use of caribou by natives of the Kenai region is difficult to judge, because few sites lie close to the optimal caribou habitat (the so-called "Caribou Hills" region). Some caribou bones have been found in Kachemak Bay sites, such as the Fox Farm site on Yukon Island, to the southwest of the Caribou Hills (Yesner, 1988).

However, assuming that our current archaeological data are basically correct, it appears that human foragers in the interior of the Kenai Peninsula opted for a subsistence strategy of relatively wide dietary breadth, focusing on resources which (a) are reliable and easy to catch, particularly in winter (e.g., hare); (b) have a high body fat content, particularly in winter (e.g., marmot); and/or (c) are storable (e.g., anadromous fish). Of course, trade relations may have been necessary to supply caribou hide for clothing and babiche for snowshoe manufacture, as noted above. Hare skins would also have been useful, however, because, as noted by McClellan (1975), hare skin robes were simultaneously light and warm. Workman (1978:19) notes that "the value of this resource was enhanced since it could be exploited by women, children, and the aged at any time of year." Thus, "the snowshoe rabbit, although subject to drastic fluctuations on a ten-year cycle, was probably very important in subsistence when available."

In other Dena'ina settlements outside of the Kenai Peninsula in which caribou populations were more available, a somewhat different subsistence pattern emerges. For example, at the late (historic) Kijik site, located to the west of Cook Inlet, the faunal assemblage was dominated by large game, which constituted $49.4 \%$ of the faunal elements; these included some moose, but were again dominated by caribou remains. Snowshoe hare, as at Dakah De'nin's Village, was secondary in importance, constituting $34.7 \%$ of the assemblage; beaver was third in importance, being $12 \%$ of the assemblage; and other fur-bearers constituted only $3.4 \%$ of the total (VanStone and Townsend, 1970). Comparing the Sterling and Kijik sites to others in the southern coastal region is somewhat difficult, since none of these apparently represents exclusive summer encampments; on the other hand, it does make the sites more comparable.

For those groups inhabiting the coastal portions of the boreal forest, then, subsistence was based primarily on a "fish and hare" type of pattern that has been well described for other boreal forest groups of the eastern Subarctic. Particularly relevant in this regard is Rogers and Black's (1976) discussion of "Subsistence Strategy in the Fish and Hare Period, Northern Ontario: the Weagamow Ojibwa, 1880-1920." According to Rogers and Black, the Indians of Weagamow Lake depended primarily on caribou (and moose) hunting until the mid-1800s, when these species became scarce; this necessitated a "shift in subsistence strategy and organization of activities from big game hunting to a living that depended on fish and hare" (Rogers and Black, 1976:14). According to Rogers and Black, a critical part of that adaptation was a shift to a more central-based type of foraging, with "zones of exploitation that can expand and contract with changes in resource availability"' (Rogers and Black, 1976:1).

Berry picking and hare snaring sometimes called for moving a camp, but not always. Also, shifts over time occurred. Forest fires, for example, could alter the locations of berry patches or hare-snaring grounds vis-a-vis the home base camp. Thus, in terms of distance and/or its related factors of time and energy spent procuring food, the exact zone resorted to for particular pursuits varied to a degree. Despite these variations, however, the general picture of seasonal energy requirements and their sequential ordering holds true for all home base groups. [Rogers and Black, 1976:29.]

This pattern seems to have strong applicability to the late prehistoric Dena'ina encampments in the boreal forest zone.

Another alternative to the exploitation of large game such as caribou is the use of coastal resources. Groups of Tanaina were clearly exploiting the coastline in historic times. What is not as certain is if the interior sites on the Kenai Peninsula represent groups who spend the spring on the shoreline collecting shellfish, or whether the entire year was spent in the interior, with the coast being occupied by other groups. A certain degree of territoriality could be expected among the larger Tanaina populations of late prehistoric times on the Kenai Peninsula, which would have made permanent settlement by some groups in the interior more likely. Analysis of coastal Dena'ina settlements suggests that many of these were occupied year round. Kari (1985:15), for example, notes 
that "in the middle . . Inlet area there was a network of year-round coastal villages and regular exchange of coastal and inland products." Thus, large numbers of shellfish remains (57 individuals) at the Sterling sites probably reflect coastal-interior trade. (Although Osgood [1937:51] noted coastal-interior trade for dentalium shells, he did not discuss the type of marine clams found in the Sterling sites.) It is noteworthy that both the Dakah De'nin and Gulkana sites also showed fragments of shellfish that were probably also traded in from the coast. To what degree these were important as subsistence resources, or only for decorative purposes, is unknown. In any case, the degree to which the interior Dena'ina actually substituted coastal resources for large game is open to question.

Interestingly, some of the shell middens from the Kachemak Bay region of the Kenai Peninsula do show "significant" amounts of large game utilization; for example, as much as $8 \%$ of the meat weight represented at the Yukon Island site may be attributed to this category (Yesner, 1988). However, $99 \%$ of those remains are of caribou, and of those, most of the remains are either related to antler or metapodial reduction for bone tool manufacture (cf. Yesner and Bonnichsen, 1979). Only two isolated moose bones are known from the entire site.

The Kachemak Bay sites are, of course, Eskimo rather than Indian sites, dating from ca. 3000 to ca. $1500 \mathrm{yr}$ B.P. Other Eskimo sites also contain occasional isolated moose bones. However, as in Indian sites, these tend universally to be late prehistoric in age and to represent a very small proportion of the total faunal assemblage. As for the Indian sites, the Eskimo from southern Alaska tend to have somewhat larger numbers of moose bones; for example, VanStone (1967) found that in four house excavations in the Nushagak River drainage, moose contributed $6.1 \%$ of the faunal assemblages. In more northerly Eskimo sites, however, the moose contribution is negligible. For example, at the Late Thule Washout site on Herschel Island, in the MacKenzie District of the northern Yukon, which has dates of 1510-1570 yr B.P., moose bones are present (Yorga, 1980:53,131) but constitute less than $1 \%$ out of a total sample of 10000 faunal elements. Similarly, at the late prehistoric Kangiguksuk site in northern Alaska (Hall, 1971), moose contributed only $0.6 \%$ of the total faunal assemblage.

\section{DISCUSSION}

Our ability to achieve these kinds of reconstructions of late prehistoric subsistence and settlement in the boreal forest is, of course, limited by a host of taphonomic factors that affect the interpretations of all faunal assemblages. These include the standard preservational problems in the boreal forest region, as well as cultural practices that modify the faunal assemblages. In particular, the latter include wellknown special treatments given to bones of different animal species. However, two problems seem to be present here. First, different Athapaskan groups had apparently different taboo patterns related to the treatment of bones, making this correction factor essentially non-comparable between groups. Second, excavations undertaken in different regions suggest that few of these practices can be satisfactorily demonstrated in the archaeological record (Janes, 1983). For example, Holmes (1986a:211) notes that Koyukon cultural practices included taboos against the burning of caribou and moose bones but allowed the burning of bear, beaver, and hare bones. However, the Minchumina archaeological deposits produced examples of unburned beaver bones as well as burned caribou and moose bones. Furthermore, this cultural pattern is nearly the opposite among other Athapaskan groups such as the Ahtna, for whom the burning of caribou, moose, and sheep bones was prescribed while the burning of beaver bones was considered taboo (de Laguna, 1969/1970; de Laguna and McClellan, 1981). Again, however, the archaeological data do not match: at the Gulkana site, numerous burned beaver bones were found (Lobdell, 1976).

What we end up with is a series of cautionary tales concerning the linkages between historically known Athapaskan subsistence patterns and the late prehistoric record. The example of taboos in the treatment of animal bones illustrates our inability always to assume a one-to-one correspondence between ethnographic and archaeological observations. The same cautionary tale can be addressed to the subsistence patterns themselves. Simply because Athapaskan tradition sites are deemed ancestral to modern Athapaskan groups does not mean that all subsistence and settlement patterns were the same in late prehistoric times as at present. Nor does it mean that we should expect them to stay fixed with time. The evidence developed in this paper suggests that, in particular, the modern linkage of Athapaskans and moose populations is very recent in origin.

In addition, the evidence presented here suggests that climatic changes, changes in frequency of fires, and changes in the dynamics of large game populations must all have contributed to substantial shifts in subsistence practices and, in some cases, movements of human populations. Some of these effects were more likely to be found in patchier environments and those more marginal for caribou production because of snow depth, fire effects, or topography. In those areas, such as on the Kenai Peninsula, a wider dietary breadth (more "diffuse" subsistence in Cleland's terms) and a central-based settlement pattern, coupled with extensive trade relations, would have allowed a flexible adaptation to such changing circumstances.

\section{CONCLUSION}

Archaeological data from various parts of the western Subarctic show very little evidence of the utilization of moose in prehistoric times. Archaeological assemblages containing moose bones tend universally to be late, and usually historic, in age. The archaeological data tend to substantiate biological and ethnohistorical data that suggest that moose became much more important in the western boreal forest only during historic times, and particularly the 20th century. Caribou appears to have been the species of primary importance, particularly in the north; in the southern coastal region, small game and fish may have always been the primary basis of subsistence.

\section{ACKNOWLEDGEMENTS}

This paper grew out of an earlier version presented to the Alaska Anthropological Association in Fairbanks and a later version presented to the Society of American Archaeology in Toronto. Funding for research on the faunal remains from the Squilantnu 
(Sterling) sites, Kenai Peninsula, southcentral Alaska, was provided by the Office of History and Archaeology, Alaska Department of Natural Resources. I thank Wendy Arundale and Kris Crossen for encouragement to write this paper; Bill Workman, Don Clark, Polly Quick, Chris Hanks, and David Klein for comments on various earlier versions of the manuscript; Chuck Holmes for access to the Squilantnu and Minchumina Lake data; Don Clark, for supplying unpublished archaeological and ethnohistoric data from the Koyukuk River region; Herb Maschner, Bob Betts, Jack Lobdell, and Becky Saleeby for access to unpublished data from Alaskan interior sites; and Bruce Winterhalder and Harvey Feit for intellectual stimulation. Figure 1 was drafted by Ellen McKay. All errors, of course, are my own.

\section{REFERENCES}

AGER, T.A. 1982. Vegetational history of western Alaska during the Wisconsin glacial interval and the Holocene. In: Hopkins, D.W., and Young, J.C., eds. Paleoecology of Beringia. Orlando: Academic Press.

1983. Holocene vegetational history of Alaska. In: Wright, H.E. Jr., ed. Quaternary Environments of the United States. Minneapolis: University of Minnesota Press.

1984. Vegetation changes in southcentral Alaska since deglaciation. Program and Abstracts, American Quaternary Association 8:1. 1985. Postglacial pollen and tephra records from lakes in the Cook Inlet region, southern Alaska. Palynology 9:235.

and BRUBAKER, L., eds. 1985. Quaternary palynology and vegetational history of Alaska. In: Bryant, V.M., Jr., and Holloway, R.G., eds. Pollen Records of Late-Quaternary North American Sediments. New York: AASP Foundation.

AGER, T.A., and SIMS, J.D. 1981a. Late Quaternary pollen record from Hidden Lake, Kenai Peninsula, Alaska. Program and Abstracts, American Association of Stratigraphic Palynologists 14:8-9.

1981b. Holocene pollen and sediment record from the Tangle Lakes area, central Alaska. Palynology 5:85-98.

ALLEN, J.A. 1904. List of mammals collected by the A.J. Stone expedition of 1903. American Museum of Natural History Bulletin 20:273-292.

ANDERSON, R.M. 1974. Range of moose extending northward. Canadian Field-Naturalist 38:27-29.

BARNEY, R.J. 1971. Wildfires in Alaska - some historical and projected effects. In: Slaughter, C.W., Barney, R.J., and Hansen, G.M., eds. Fire in the Northern Environment. Portland, Oregon: Pacific Northwest Forest and Range Experiment Station.

BETTS, R. 1988. Archaeological Investigations at Butte Lake, Alaska: A Report to the University of Alaska Museum Geist Fund. Department of Anthropology, University of Alaska, Fairbanks, Alaska 99775.

BINFORD, L.R. 1978. Nunamiut Ethnoarchaeology. New York: Academic Press.

BISHOP, R.H., and RAUSCH, R.A. 1974. Moose population fluctuations in Alaska, 1950-1972. Naturaliste Canadien 101:559-593.

BURCH, E.S., Jr. 1972. The caribou/wild reindeer as a human resource. American Antiquity 37:339-368.

CAMPBELL, J. n.d. Ahtna Field Notes. Cited in Shinkwin (1979).

CHATELAIN, E.F. 1952. Distribution and abundance of moose in Alaska. Proceedings of the Alaska Science Conference 3:134-136.

CLARK, A. n.d. Koyukuk Koyukon settlement pattern and social organization: precontact to 1910 . Unpubl. National Museum of Civilization, Ottawa, Ontario, Canada K1A OM8.

CLELAND, C.E. 1966. The Prehistoric Animal Ecology and Ethnozoology of the Upper Great Lakes Region. Ann Arbor: University of Michigan Museums, Anthropological Papers 29.

COADY, J.W. 1974. Influence of snow on behavior of moose. Naturaliste Canadien 101:417-436.

CROSSEN, K.J. 1988. Holocene dynamics of the Spencer-Blackstone ice field, Kenai Mountains, southcentral Alaska. American Quaternary Association Abstracts.

De LAGUNA, F. 1969/1970. The Ahtna of the Copper River, Alaska: the world of men and animals. Folk 11/12:17-26.

and MCCLELLAN, C. 1981. Ahtna. In: Helm, J., ed. Subarctic, Handbook of North American Indians. Vol. 6. Washington, D.C.: Smithsonian Institution Press.

DIXON, E.J., SMITH, G., SALEEBY, B., UTERMOHLE, C., and ANDREFSKY, W. 1985. Susitna Hydroelectric Project Cultural Resources
Investigations, 1979-1985. Vol. I. Fairbanks: University of Alaska Museum.

DIXON, R.G. 1980. The Moose River site: a preliminary report. In: Dilliplane, T.L., ed. Archaeological Survey Projects, 1978. Anchorage: Alaska Department of Natural Resources, Office of History and Archaeology Series 22.

FEIT, H.A. 1969. Mistassini Hunters of the Boreal Forest: Ecosystem Dynamics and Multiple Subsistence Patterns. M.A. thesis, Department of Anthropology, McGill University, Montreal.

GADACZ, R.R. 1975. Montagnais hunting dynamics in historicoecological perspective. Anthropological 17:149-168.

GRONNOW, B., MELDGAARD, M., and NIELSEN, J.B. 1983. Aasivissiut - The Great Summer Camp. Archaeological, ethnographical, and zooarchaeological studies of a caribou-hunting site in West Greenland. Meddelelser om Gronland, Man and Society 5.

HADLEIGH-WEST, F. 1966. Archaeology of Ogotoruk Creek. In: Wilimovsky, N.J., and Wolfe, J.N., eds. Environment of the Cape Thompson Region. Washington, D.C.: U.S. Atomic Energy Commission.

HALL, E.S. 1971. Kaniguksuk: a Cultural Reconstruction of a Sixteenth Century Eskimo Site in Northern Alaska. Arctic Anthropology 8(1):1-101.

HARDY, C.E., and FRANKS, J.W. 1963. Forest fires in Alaska. Washington, D.C.: U.S. Forest Service, Research Paper INT-5.

HATTER, J. 1948. The status of moose in North America. Transactions of the North American Wildlife Conference 14:492-501.

HELMER, J.W., VAN DYKE, S., and KENSE, F.J., eds. 1977. Prehistory of the North American Subarctic: The Athapaskan Question. Calgary: University of Calgary, Chacmool.

HEMMING, J.E. 1972. The Distribution and Movement Patterns of Caribou in Alaska. Juneau: Alaska Department of Fish and Game, Wildlife Technical Bulletin 1.

HOLMES, C.E. 1986a. The Prehistory of the Lake Minchumina Region, Alaska. Anchorage: Alaska Anthropological Association, Aurora 2. 1986b. Supplemental Report: Sterling Highway Archaeology, 1985-1986. Anchorage: Alaska Department of Natural Resources, Office of History and Archaeology Public Data File 86-35.

JANES, R.R. 1983. Archaeological Ethnography among Mackenzie Basin Dene, Canada. Calgary: Arctic Institute of North America Technical Paper 28.

KARI, J. 1985. Some Linguistic Insights into Dena'ina Prehistory. Paper presented to the American Society for Ethnohistory, Chicago. Available at Subsistence Division, Alaska Department of Fish and Game, Raspberry Road, Anchorage, Alaska 99510, U.S.A.

KETZ, J.A. 1983. Paxson Lake: Two Nineteenth Century Ahtna Sites in the Copper River Basin, Alaska. Fairbanks: University of Alaska, Cooperative Parks Studies Unit.

KLEIN, D.R. 1965. Postglacial distribution patterns of mammals in the southern coastal regions of Alaska, Arctic 18:7-20.

KOLAR, J.C. 1980. Some Aspects of Faunal Utilization at the Old Chief Creek Site (MjVk-7). Paper delivered to the Canadian Archaeological Association. Available at the Department of Anthropology, University of Toronto, Toronto, Ontario, Canada.

LeBLANC, R.J. 1984. The Rat Indian Creek Site and the Late Prehistoric Period in the Northern Yukon. Ottawa: National Museum of Man, Archaeological Survey of Canada, Mercury Series 120.

LEOPOLD, A.S., and DARLING, F.F. 1953. Effects of land use on moose and caribou in Alaska. Transactions of the North American Wildlife Conference 18:553-562.

LERESCHE, R.E., BISHOP, R.H., and COADY, J.W. 1974. Distribution and habitats of moose in Alaska. Naturaliste Canadien 101:143-178.

LEWIS, H.T. 1977. Maskuta: the ecology of Indian fires in northern Alberta. In: McCormack, P., ed. Environmental Manipulation. Western Canadian Journal of Anthropology 7.

LOBDELL, J.E. 1976. Considerations on Late Prehistoric Atna Seasonal Nutrition. Unpubl. ms. Available at the Department of Anthropology, University of Alaska, 3211 Providence Drive, Anchorage, Alaska 99508, U.S.A.

n.d. KEN-043, Moose River Site Fauna. Unpubl. ms. Available at Office of History and Archaeology, Alaska Department of Natural Resources, Frontier Building, 36th and " $C$ " Streets, Anchorage, Alaska 99510, U.S.A.

WTZ, H.J. 1956. Ecological Effects of Forest Fires in the Interior of Alaska. Washington, D.C.: U.S. Department of Agriculture, Technical Bulletin 1133.

1959. Early fires of unknown origin in the boreal forest of Alaska. Aboriginal Man and White Man as Historical Causes of Fires in the Boreal Forest, with Particular Reference to Alaska. New Haven: Yale University School of Forestry Bulletin 65. 
1960. Early Occurrence of Moose on the Kenai Peninsula and in Other Sections of Alaska. Juneau: Alaska Forest Research Center, Miscellaneous Publication 1.

MASCHNER, H.F. 1987. Temporary Use of a Permanent Structure: An Example from Tazlina Lake. Paper presented to the Alaska Anthropological Association, Fairbanks. Available at the Department of Anthropology, University of California, Santa Barbara, California 93106, U.S.A.

MCCLELLAN, C. 1975. My Old People Say: An Ethnographic Survey of the Southern Yukon Territory. Ottawa: National Museums of Canada, Publications in Ethnology 6. 2 vols.

McMAHAN, J.D. 1986. Ramifications of Macrobotanical Recovery and Analysis for Late Prehistoric Plant Use on the Kenai Peninsula. Paper presented to the Alaska Anthropological Association, Fairbanks. Available at Office of History and Archaeology, Alaska Department of Natural Resources, Frontier Building, 36th and "C"' Streets, Anchorage, Alaska 99510, U.S.A.

MERRITT, J.F. 1984. Winter Ecology of Small Mammals. Pittsburgh: Carnegie Museum of Natural History.

MORLAN, R.E. 1973. The Later Prehistory of the Middle Porcupine Drainage, Northern Yukon Territory. Ottawa: National Museum of Man, Archaeological Survey of Canada Mercury Series 11.

MURIE, O.J. 1935. Alaska-Yukon Caribou. Washington, D.C.: U.S. Government Printing Office.

NELSON, R.K. 1973. Hunters of the Northern Forest: Designs for Survival among Alaskan Kutchin. Chicago: University of Chicago Press.

O'CONNELL, J.F., HAWKES, K., and BLURTON JONES, N. 1988a. Hadza scavenging: implications for Plio/Pleistocene hominid subsistence. Current Anthropology 29(2):356-363.

1988b. Hadza Hunting, Butchering, and Bone Transport and Their Archeological Implications. Journal of Anthropological Research 44(2):113-161.

OSGOOD, C. 1937. The Ethnography of the Tanaina. New Haven: Yale University Press.

OSGOOD, W.H. 1904. Natural History of the Cook Inlet Region, Alaska. Washington, D.C.: U.S. Bureau of Biological Survey, North American Fauna 21.

PLASKETT, D.C. 1977. The Nenana River Gorge Site: A Late Prehistoric Athapaskan Campsite in Central Alaska. M.A. thesis, University of Alaska, Fairbanks.

REAM, B.A. 1986. Old Fish Camp: An Ethnohistoric and Archeological Analysis of a Lower Koyukon Athapaskan Winter Village, Khotol River, Alaska. M.A. thesis, Western Washington University, Bellingham.

ROGERS, E.S., and BLACK, M.B. 1976. Subsistence strategy in the Fish and Hare period, northern Ontario: the Weagamow Ojibwa, 1880-1920. Journal of Anthropological Research 32:1-43.

SALEEBY, B.M., and DIXON, E.J. 1986. Archaeological Evidence for Caribou and Moose Utilization on the Middle Susitna River, Southcentral Alaska. Paper presented to the Alaska Anthropological Association, Fairbanks. Available at University of Alaska Museum, University of Alaska, Fairbanks, Alaska 99775, U.S.A.

SCHWATKA, F. 1892. A Summer in Alaska: A Popular Account of an Alaskan Exploring Expedition. Philadelphia: Huber.

SHINKWIN, A.D. 1979. Dakah De'nin's Village and the Dixthada Site: A Contribution to Northern Athapaskan Prehistory. Ottawa: National Museum of Man, Archaeological Survey of Canada Mercury Series 91. SKOOG, R.O. 1968. Ecology of the Caribou in Alaska. Ann Arbor: University Microfilms.
SPENCER, D.H., and HAKALA, J. 1964. Moose and fire on the Kenai Proceedings of the Annual Tall Timbers Fire Ecology Conference 3:10-33.

SPIESS, A.E., and GERLACH, C.S. 1983. Observations on the Faunal Remains from the Croxton Site, Tukuto Lake, Alaska. Paper presented to the Alaska Anthropological Association, Anchorage. Available at University of Alaska Museum, University of Alaska, Fairbanks, Alaska 99775, U.S.A.

VANSTONE, J.W. 1967. Eskimos of the Nushagak River. Seattle: University of Washington Press.

1974. Athapaskan Adaptations: Hunters and Fishermen of the Subarctic Forests. Chicago: Aldine.

and TOWNSEND, J.B. 1970. Kijik: An Historic Tanaina Indian Settlement. Chicago: Field Museum of Natural History, Fieldiana 59.

VIERECK, L.A. 1973. Wildfire in the taiga of Alaska. Quaternary Research 3:465-495.

WEIN, R.W., and MACLEAN, D.A. 1983. The Role of Fire in Northern Circumpolar Ecosystems. New York: Wiley.

WILMSEN, E.N. 1973. Interaction, spacing behavior, and the organization of hunting bands. Journal of Anthropological Research 29:1-31.

WINTERHALDER, B. 1982. Boreal foraging strategies. In: Steegmann, A.E., ed. Boreal Forest Adaptations. New York: Academic Press.

WORKMAN, W.B. 1977. Ahtna archaeology: a preliminary statement. In: Helmer, J., Van Dyke, S., and Kense, F.J., eds. Prehistory of the North American Subarctic: the Athapaskan Question. Calgary: University of Calgary, Chacmool.

1978. Prehistory of the Aishihik-Kluane Area, Southwest Yukon Territory. Ottawa: National Museums of Canada, Mercury Series 74.

YARBOROUGH, M.R. 1983. Survey and Testing of SEW 175/176 and SEW 187, Kenai Peninsula, Alaska. Report to the Alaska Department of Transportation and Public Facilities, Anchorage. Available at Office of History and Archaeology, Alaska Department of Natural Resources, Frontier Building, 36th and 'C"' Streets, Anchorage, Alaska 99510, U.S.A.

YESNER, D.R. 1980. Caribou exploitation in interior Alaska: paleoecology at Paxson Lake. Anthropological Papers of the University of Alaska 19:15-31.

1981. Archaeological applications of optimal foraging theory: harvest strategies of Aleut hunter-gatherers. In: Winterhalder, B., and Smith, E.A., eds. Hunter-gatherer Foraging Strategies: Ethnographic and Archaeological Analyses. Chicago: University of Chicago Press. 1986. Faunal Assemblages at Sites SEW-214, KEN-092, and KEN-094, in the Vicinity of the Sterling Highway, Kenai Peninsula, Alaska. In: Holmes, C.E., ed. Supplemental Report: Sterling Highway Archaeology, 1985-1986. Anchorage: Alaska Department of Natural Resources, Public Data File 86-35.

1988. Subsistence and Settlement Patterns of the Kachemak Tradition, Cook Inlet, Southcentral Alaska: the Faunal Evidence. Paper presented to the Kodiak Native Heritage Conference, Kodiak, Alaska. Available at The Department of Anthropology, University of Alaska, 3211 Providence Drive, Anchorage, Alaska 99508, U.S.A. and BONNICHSEN, R. 1979. Caribou metapodial shaft splinter technology. Journal of Archaeological Science 6:303-308.

YORGA, B.W.D. 1980. Washout: a Western Thule Site on Herschel Island, Yukon Territory. Ottawa: National Museums of Canada, Mercury Series 98.

ZAGOSKIN, L.A. 1967. (Originally published in 1839.) Lieutenant Zagoskin's Travels in Russian America. In: Michael, H.N., ed. Toronto: Arctic Institute of North America and University of Toronto Press. Anthropology of the North: Translations from Russian Sources 7. 